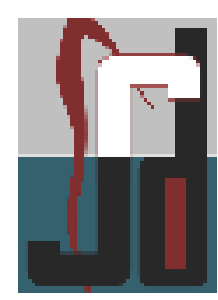

REVIEW

\title{
INTEGRATED FLUOROSIS MITIGATION - AN INDIAN PERSPECTIVE
}

Pavithra $\mathrm{R}^{1}$, Madan Kumar PD ${ }^{2}$

ABSTRACT_India is one among the 23 nations identified as fluoride endemic regions. The concentration of fluoride in the groundwater ranges from $1.0 \mathrm{mg} / 1$ to $48.0 \mathrm{mg} / \mathrm{l}$, while The Bureau of Indian Standards has set $1.0 \mathrm{mg} / \mathrm{l}$ as the acceptable limit. The constant exposure to fluoride through food and drinking water results in dental, skeletal and non-skeletal fluorosis. To mitigate the effects of fluoride, an Integrted approach is needed as it is advantageous than the conventional defluoridation techniques. The Integrated Fluorosis Mitigation approach imparts better understanding of the adverse effects of fluoride consumption through Information, Education and Communication activities. Using data from dental survery and Quantitative Chemical Risk Assessment tool, the hazard is identified and risk is characterised. Based on these data, mitigation strategies are planned. This review outlines the process of Integrated Fluorosis Mitigation and various programmes undertaken by the various Indian state and central governmental agencies.

Kev words: fluorosis mitigation, nutritional supplementation, quantitative chemical risk assessment.

\section{INTRODUCTION}

Water is the major constituent of our body (about $60 \%$ by weight) and is vital for life. We need to pay attention to what we are drinking throughout the day to ensure that we meet our water needs. Less than $3 \%$ of the world's water is fresh, the rest is sea water and undrinkable. Of this $3 \%$, over $2.5 \%$ is locked up in the Arctic and Antarctic glaciers, leaving only $0.5 \%$ for human needs. ${ }^{1}$ Water is needed to ensure food security, feed livestock, maintain organic life, take up industrial production and to conserve the biodiversity and environment. Hence, there is no life without water. Table 1 presents the per capita water use in different continents.

Table 1. Per Capita Water Use

\begin{tabular}{|c|c|}
\hline Continents & $\begin{array}{c}\text { Per Capita } \\
\text { Water Use } \\
\text { (m3/yr) }\end{array}$ \\
\hline Africa & 245 \\
\hline Asia & 519 \\
\hline North and S. America & 1861 \\
\hline South America & 478 \\
\hline Europe & 1280 \\
\hline USSR (Former) & 713 \\
\hline
\end{tabular}

It is estimated that the per capita water use in India will increase from the current level of 99 litres per day to 167 litres per day by $2050.83 \%$ of the current water needs are directed towards agricultural purposes, $12 \%$ for industrial purpose and $5 \%$ for domestic needs. ${ }^{2}$

The major concern of government of all nations is provision of safe and wholesome drinking water to the community. The guidelines for safe drinking water given by the World Health Organisation mentions acceptable parameters for organic and inorganic constituents. ${ }^{3}$ The government of developing nations are constantly reviewing and evolving new strategies to achieve this goal.

\section{SCENARIO OF WATER RESOURCES IN INDIA}

With $16 \%$ of world's population, India has only $4 \%$ of global water resources. Over exploitation of finite groundwater resources has resulted in exploring deep aquifers which contain high level of minerals such as fluoride and arsenic which have leached from the deep basaltic rocks. ${ }^{5}$ The high level of fluoride in the groundwater can result in dental, skeletal and non-skeletal fluorosis. Literature reveals that non-skeletal manifestations vary from reduced RBC count, reduced sperm count, nervousness, 
depression, tingling sensation in toes, abdominal pain and mouth sores. This is of great concern as $80 \%$ of domestic needs in rural India are met by groundwater. ${ }^{6}$

The global burden of disease due to fluoride in drinking water was estimated by Fewtrell et al in $2006 .^{7}$ It has been estimated in the study, that in India, about $1,81,97,000$ are affected with dental fluorosis and 78,89,000 are affected with skeletal fluorosis. The study also estimated skeletal fluorosis attributed DALY (Disability Adjusted Life Years) as 17 per 1000 .

In India, the extent of fluoride in drinking water ranges from 1.0 to $48.0 \mathrm{mg} / \mathrm{L} .{ }^{4}$ World Health Organisation has set the upper limit of fluoride concentration in drinking water at $1.5 \mathrm{mg} / \mathrm{L} .{ }^{3}$ The Bureau of Indian Standards has $1.0 \mathrm{mg} / \mathrm{L}$ as acceptable limit with remark as "the lesser the better."

Studies by Whyte et $\mathrm{a}^{9}$ and Cao et $\mathrm{a}^{10}{ }^{10}$ identified food as a potential hazard and states that food consumption may increase the risk of fluorosis. Indeed, it is clear that establishment of water quality standard of 1.0 to $1.5 \mathrm{mg} / \mathrm{L}$ for fluoride consumption through drinking water alone is not enough to mitigate the adverse health effects of fluoride.

Literature provides convincing evidence to justify the important role of malnutrition and dietary habits on severity of fluorosis. Jolly et al highlighted the role of nutritional factors relative to different clinical patterns of fluorosis seen in India. ${ }^{11}$ Liang et al showed $43.8 \%$ prevalence of skeletal fluorosis with adequate nutrition and $69.2 \%$ in those with malnutrition. ${ }^{12}$ These studies outline that health and nutritional status play important role in fluorosis.

In early 1930s, fluorosis was reported only in 4 states in India, in 1986 it was 13, in 1992 it was 15 and currently it is 20 states, indicating that endemic fluorosis has emerged as one of the public health problems of the country. ${ }^{13}$

\section{EARLY INITIATIVES TAKEN BY THE GOVERNMENT}

Due to lack of substantial data on the extent of fluorosis during the early 1980 s, extensive research was encouraged. By 1986, The Technology Mission on Safe Drinking Water was launched in India by THE THEN Prime Minister Sri Rajiv Gandhi and a submission named, "Control Of Fluorosis" was also launched. ${ }^{4}$

A fluorosis control cell was supported by the Government ofIndiaat theAllIndiaInstituteofMedical Sciences for co-ordinating the activities between the water supply and health departments of the 13 state Governments where excess fluoride and fluorosis was known to be endemic. ${ }^{4}$

The conventional fluorosis mitigation approach mainly deals with defluoridation of water, however, it cannot be proposed as the most effective solution to mitigate fluorosis. Fluorosis mitigation approach needs to begin with better understanding of health impacts of excessive fluoride intake in relation with nutritional aspects and establishing tolerable levels of risk to human health. ${ }^{5}$ These aspects are fulfilled by Integrated Fluorosis Mitigation, introduced by NEERI and UNICEF in Madhya Pradesh.

\section{STEPS INVOLVED IN INTEGRATED FLUOROSIS MITIGATION}

Integrated Fluorosis Mitigation includes understanding health impacts of excessive fluoride intake through Information, education and Communication. Establish tolerable levels of risk to human health through Quantitative Chemical Risk Assessment(QCRA), followed by development of specific strategy for effective mitigation of fluorosis such as water management solutions, domestic level defluoridation of drinking water and nutritional supplementation. This approach addresses high levels of fluoride from various exposure routes and impact of nutritional behaviour and malnutrition towards fluorosis. ${ }^{5}$

Quantitative Chemical Risk Assessment, with data from health surveys, provides the basis for use based separation of water sources. Groundwater consumption can be reduced by creating alternative water resources such as rainwater harvesting, re-use of greywater for sanitation/gardening. Development of improved and simple process for defluoridation of drinking water at household level could be 
an effective way of defluoridation of drinking water. $^{5}$

\section{QUANTITATIVE CHEMICAL RISK ASSESSMENT}

Quantitative Chemical Risk Assessment tool is used to determine an acceptable level of risk and appropriate water quality. QCRA includes information available on exposure routes such as food and water and dose-response to produce estimates of the disease burden associated with exposure to chemical. Based on exposure to chemicals and doseresponse, the risk is characterised and management options are prioritized. QCRA has four steps as follows:

\section{A. HAZARD IDENTIFICATION:}

food and water samples are analysed to determine the hazard.

\section{B. EXPOSURE ASSESSMENT:}

pathways of exposure, magnitude and frequency are identified to calculate tolerable daily intake.

\section{DOSE RESPONSE:}

epidemiological and medical screening will denote dose response.

\section{RISK CHARACTERISATION:}

data collected on fluoride exposure, dose response, severity and disease burden are brought together for risk characterisation. Prescribed physical exercises can be undertaken in communities.

The process of QCRA characterises low, moderate and high fluorosis risk in terms of DALY as follows:

\section{Water Management Solutions}

Water management solutions are based on the

\begin{tabular}{|c|c|}
\hline $\begin{array}{c}<10 \text { per } 1000 \\
\text { population }\end{array}$ & $\begin{array}{c}<10 \text { per } 1000 \\
\text { population }\end{array}$ \\
\hline $\begin{array}{c}<10 \text { per } 1000 \\
\text { population }\end{array}$ & $\begin{array}{c}<10 \text { per } 1000 \\
\text { population }\end{array}$ \\
\hline $\begin{array}{c}>100 \text { per } 1000 \\
\text { population }\end{array}$ & High \\
\hline
\end{tabular}

concentration of fluoride in drinking water. For concentration $<3 \mathrm{mg} / \mathrm{L}$, dilution techniques are used, while defluoridation techniques are used for concentration $>3 \mathrm{mg} / \mathrm{L} .^{5}$

The dilution method involves collection of rainwater from individual households and schools in storage tanks. The collected rainwater and fluoride contaminated groundwater are allowed to mix and drawn through hand pump or pipes ensuring safe water for cooking and drinking purposes. Promotion of greywater reuse reduces demand on groundwater by $60 \%$ thereby resulting in decreased levels of fluoride.

Common defluoridation techniques used can be categorised into precipitation based techniques and adsorption and ion exchange based techniques. ${ }^{14}$ other techniques such as reverse osmosis, membrane based techniques, electrodialysis, donnan dialysis and lime reactor have been efficient. However, Integrated Fluorosis Mitigation approach directed attention towards development of cost effective and simple adsorbent materials such as alumina, bauxite and bone char. Domestic level defluoridation techniques like Bamboo column, stacked mutka and Nalgonda Technique were promoted for use in ruralmareas. ${ }^{2}, 12$

\section{Nutritional Supplementation}

Chinoy et al reported that nutrient supplementation is necessary to reduce fluoride induced liver toxicity and for recovery. ${ }^{15}$ Community based studies by Krishnamachari et al reported that calcium supplementation reverses bone changes seen in fluorosis. ${ }^{16}$

Cassia tora (Chakoda Bhaji) a vegetable grown commonly in rural areas has very high calcium content $(3200 \mathrm{mg} / 100 \mathrm{~g}$ of dry leaves).5 Chakma et al reported that consumption of Chakoda Bhaji resulted in reversal of skeletal fluorosis. ${ }^{17}$ Hence consumption of Chakoda Bhaji is promoted as a part of Integrated Fluorosis Mitigation.

List Of Various Fluorosis Mitigation Projects Lauchned And Evlauted In 


\section{Different Indian States/Regions}

\begin{tabular}{|c|c|c|c|c|}
\hline S.NO & Place/project & Initiating authority & Strategy used & Outcome \\
\hline 1. & $\begin{array}{l}\text { Dungarpur, Rajasthan } \\
\text { - Project SARITA in } \\
1996 . .^{18}\end{array}$ & UNICEF & $\begin{array}{l}\text { Nalgonda based drum } \\
\text { sets and Activated } \\
\text { alumina }\end{array}$ & $\begin{array}{l}800 \text { households of five villages } \\
\text { opted both the techniques. } \\
\text { Significant relief from non- } \\
\text { skeletal symptoms. } \\
\text { Households owned Activated } \\
\text { Alumina filters and Nalgonda } \\
\text { drum sets. }\end{array}$ \\
\hline 2. & $\begin{array}{l}\text { Jhabua district, } \\
\text { Madhya Pradesh. } \\
\text { Integrated Fluorosis } \\
\text { Mitigation, 2005.5 }\end{array}$ & NEERI and UNICEF & $\begin{array}{l}\text { Information education } \\
\text { and communication } \\
\text { activities, QCRA, } \\
\text { Water dilution } \\
\text { solutions and } \\
\text { nutritional } \\
\text { supplementation. }\end{array}$ & $\begin{array}{l}\text { Reversal of skeletal fluorosis. } \\
86 \% \text { reduction in grade I } \\
\text { fluorosis, } 77 \% \text { reduction in grade } \\
\text { II fluorosis and } 60 \% \text { reduction in } \\
\text { grade IV fluorosis. }\end{array}$ \\
\hline 3. & $\begin{array}{l}\text { Dhar district, Madhya } \\
\text { Pradesh, } 2008 \cdot{ }^{19} \mathrm{~A} \\
\text { Pilot study. }\end{array}$ & $\begin{array}{l}\text { People's science } \\
\text { institute, Vasudha } \\
\text { Vikas Sansthan and } \\
\text { Water Aid, India. }\end{array}$ & $\begin{array}{l}\text { Assess prevelance } \\
\text { of fluorosis, water } \\
\text { quality testing of } \\
\text { all water sources, } \\
\text { Fluorosis mitigation } \\
\text { interventions. }\end{array}$ & $\begin{array}{l}\text { The intervention has been } \\
\text { implemented in } 24 \text { clusters } \\
\text { identified from } 8 \text { panchayats. }\end{array}$ \\
\hline 4. & $\begin{array}{l}\text { Tumkur district, } \\
\text { Karnataka. Sachetana } \\
\text { Plus, 2006. }\end{array}$ & $\begin{array}{l}\text { BAIF Institute for } \\
\text { Rural Development, } \\
\text { Karnataka. } \\
\text { Rural Development } \\
\text { and Panchayati Raj } \\
\text { Department. }\end{array}$ & $\begin{array}{l}\text { Rooftop rainwater } \\
\text { harvesting, recharge } \\
\text { of borewells, direct } \\
\text { aquifer recharge. }\end{array}$ & $\begin{array}{l}5600 \text { rain water harvesting } \\
\text { structures were constructed. } \\
\text { Creation of artificial catchment } \\
\text { and recharge of borewells. }\end{array}$ \\
\hline 5. & $\begin{array}{l}\text { Sonbhadra, Uttar } \\
\text { Pradesh. Fluorosis } \\
\text { Mitigation Project, } \\
2004 .{ }^{21}\end{array}$ & $\begin{array}{l}\text { People’s Science } \\
\text { Institute, Banwasi } \\
\text { Seva Ashram. }\end{array}$ & $\begin{array}{l}\text { Health assessment, } \\
\text { water quality } \\
\text { management, } \\
\text { Public awareness } \\
\text { programmes, } \\
\text { nutritional } \\
\text { intervention. }\end{array}$ & $\begin{array}{l}2146 \text { household and } 970 \text { children } \\
\text { were benifited from this project. }\end{array}$ \\
\hline 6. & $\begin{array}{l}\text { Naupada District, } \\
\text { Orissa. Fluorosis } \\
\text { Mitigation, 2005. }{ }^{22}\end{array}$ & $\begin{array}{l}\text { People's Science } \\
\text { Institute and Sahbhagi } \\
\text { Vikash Abhiyan. }\end{array}$ & $\begin{array}{l}\text { Conversion of dug } \\
\text { wells into safe sanitary } \\
\text { wells, construction of } \\
\text { sand wells in ponds } \\
\text { with low fluoride } \\
\text { concentration, } \\
\text { domestic defluoridation } \\
\text { kits and rainwater } \\
\text { harvesting. }\end{array}$ & 6995 beneficiaries \\
\hline
\end{tabular}




\begin{tabular}{|l|l|l|l|l|}
\hline 7. & $\begin{array}{l}\text { Nalgonda district, } \\
\text { Andhra Pradesh. }\end{array}$ & $\begin{array}{l}\text { Sai Oral Health } \\
\text { Foundation and } \\
\text { Government of Andhra } \\
\text { Pradesh }\end{array}$ & $\begin{array}{l}\text { Rainwater harvesting } \\
\text { system and bone char } \\
\text { based defluoridation } \\
\text { techniques. }\end{array}$ & $\begin{array}{l}38 \% \text { of decrease of urinary } \\
\text { fluoride, } 6 \% \text { increase of serum } \\
\text { calcium, } 5 \% \text { increase of serum } \\
\text { phosphorus and } 8 \% \text { increase in } \\
\text { serum alkaline phosphatase. }\end{array}$ \\
\hline 8. & $\begin{array}{l}\text { Dharmapuri } \\
\text { and Krishnagiri } \\
\text { district, Tamilnadu, } \\
\text { Hogenakkal water } \\
\text { supply and fluorosis } \\
\text { mitigation project, } \\
2008 .{ }^{24}\end{array}$ & $\begin{array}{l}\text { Government of } \\
\text { Tamilnadu. }\end{array}$ & $\begin{array}{l}\text { Fluorosis mitigation, } \\
\text { capacity building of } \\
\text { local bodies. }\end{array}$ & Ongoing project. \\
\hline
\end{tabular}

\section{CONCLUSION}

Combating fluorosis on a mass scale has remained a dream till now due to lack of massive communication programs, lack of awareness on the part of people etc. Mass media or social media can play a vital role in preventing and limiting problem of fluorosis. It is evident from studies by several researchers worldwide that fluoride in groundwater and food has been a potential problem to human society. To remediate the menace caused by fluoride, an integrated approach is needed. But ultimate solution for this fluoride menace remains to be the principal of "Prevention is better than cure".

\section{REFERENCES}

1. "Water for People, Water for Life" United Nations World Water Development Report, Part II: A look at the world's freshwater resources. UNESCO, 2003. Available from: http:// www.unesco. org

2. Narayan G. Hegde. Water Scarcity and Security in India. BAIF Development Research Foundation, Pune. Available from: www.indiawaterportal.org.

3. Guidelines for safe drinking water quality. Geneva:WHO;2004: World Health Organisation.

4. A.K.Susheela. Fluorosis in developing countries: Remedial measures and approaches. Proc Indian Nat Sci Acad. 2002; 68(5):389-400.

5. NEERI, UNICEF. Report on Integrated Fluorosis Mitigation. 2007.

6. Ayoob S, Gupta A K. Fluoride in drinking water:
A review of the status and stress effects. Critical Review. Environ Sci Tech. 2006; 36:433-487.

7. Fewtrell L, Smith S, Kay D, Bartram J. An attempt to estimate the global burden of disease due to fluoride in drinking water. J Water Health. 2006 ; 4:533-542.

8. Indian Standard Drinking Water Specification. New Delhi: Bureau of Indian Standards; 2012.

9. Whyte m P, Essmeyer k, Gannon F H, Reinus W R. Skeletal fluorosis and instant tea. Fluoride 2005 ; 38(1):76-81.

10. Cao J, Zhao Y, Li Y, Deng H J, Yi J, Lin J W. Fluoride levels in various black tea commodities: Measurement and safety evaluation. Food Chem Toxicol 2006; 44: 1131-1137.

11. Jolly S S, Singla V P, Sharma R, Ralham S M and Sandhu S S. Endocrine aspects of endemic fluorosis. Fluoride 1974; 7(4):208-219.

12. Liang C K, Ji R, Cao S R. Epidemiological analysis of endemic fluorosis in China. Environ Carcinogen. Ecotoxixol Rev 1997;15(2):123-138.

13. Susheela A K. Fluorosis: Indian Scenario: A treatise on fluorosis. Fluorosis research and rural development foundation. New Delhi, India.2001.

14. Piddennavar R, Pushpanjali K. Review on Defluoridation Techniques of Water. The International Journal of Engineering and Science. 2013;2(3):86-94.

15. Chinoy N J, Dilpi M. Beneficial effects of a protein supplementation diet on fluoride induced toxicity in liver of male mice. Fluoride 2005; 3(4):276-283 
16. Krishnamachari A K V P. Skeletal fluorosis in humans: a review of recent progress in the understanding of the disease. Prog Food Nutr Sci. 1986; 10(3):279-314.

17. Chakma T, Rao V P, Singh S B, Tiwary R S. Endemic genuvalgum and other bone deformities in two villages of Mandla district in central India. Fluoride 2000; 33(4): 17-195.

18. Vaish AK, Vaish P. A Case Study of Fluorosis Mitigation in Dungarpur District, Rajasthan, India. In: Dahi E, Rajchagool S, Osiriphan N, editors. Proceedings of the 3rd International Workshop on Fluorosis Prevention and Defluoridation of Water. 2000 Nov 20-24; Chiang Mai, Thialand. 97-104.

19. People's Science Institute, Dehradun. Vasudha Vikas Sansthan (Dhar). Water Aid, India. Report on Fluorosis mitigation program in Dhar District (M.P.) 2011.

20. Mythri H, Dinesh, Bennadi D. Current public health perspective of fluorosis mitigation project in Pavagada taluk, Karnataka. Indian J Occup Environ
Med. 2012;16(3):124-26.

21. Gautam A, Tripathi RC. Fluoride Testing and Fluorosis Mitigation In Sonebhadra District Available from: https://ideas. repec.org/p/ess/wpaper/id 1853. html.

22. Fluoride Testing and Fluorosis Mitigation nn Nuapada District Orissa: A Small Pilot-Scale Exercise.

Available from: http:// peoplesscienceinstitute. org/PDF's/EQMG/FLUORIDE\%20TESTING\%20 AND\%20FLUOROSIS\%20MITIGATION\%20IN\%20 NUAPADA.pdf.

23. Narayana AS, Khandare AL, Krishnamurthi MVRS. Mitigation of Fluorosis in Nalgonda District Villages. In: Dahi E, Rajchagool S, editors. Proceedings of the 4th International Workshop on Fluorosis Prevention and Defluoridation of Water. 2004 Mar 2-6; Colombo, SriLanka. 98-106.

24. Hogenakkal Water Supply and Fluorosis Mitigation Project. Tamilnadu Water supply and Drainage Board. Available from http://www.twadboard.gov.in/twad/ hogenakkal.

\section{Address of Correspondence}

Dr. Pavithra R, Postgraduate student, Department of Public Health Dentistry, Ragas Dental College and Hospital, 2/102, East coast road, Uthandi,

Chennai - 600119. Ph no- +91 - 9940474047

Email address-pavithraravishankar@gmail.com

\section{Authors:}

${ }^{1}$ Post Graduate Student, Dept. of Public Health Dentistry, Ragas Dental College \& Hospital, Chennai ${ }^{2}$ Professor, Dept. of Public Health Dentistry, Ragas Dental College \& Hospital, Chennai

\section{How to cite this article :}

Pavithra R, Madan Kumar PD. Integrated Fluorosis Mitigation - An Indian Perspective Journal of Scientific Dentistry $2015 ; 5(1): 30-35$

Source of Support : Nil, Confliet of Interest : None declared 